\title{
Negotiating Gender and Sexual Diversity in English Language Teaching: "Critical"- Oriented Educational Materials Designed by Pre-Service English Teachers at a South African University \\ Navan N. Govender \\ University of the Witwatersrand in Johannesburg, South Africa
}

In order to disrupt preconceptions, learners and teachers need to engage in difficult conversations. Being truly critical means that both have to step out of their own shoes to analyse and (re)evaluate their subject positions regarding social justice, diversity and power. This is no easy task and teachers and learners often avoid these risky spaces (Bhana, 2012). Such avoidance suggests that initial teacher education (ITE) take up the call to engage preservice English language teachers with controversial topics such as those related to gender and sexual diversity as well as the conflations between these. Critical literacy, as an approach to teaching and learning languages, becomes useful for confronting such controversies by asking teachers and learners to deconstruct, disrupt and reconstruct (Janks, 2010a) the texts around them in socially just ways. In this chapter I take up the call to engage ELT students in processes of negotiating gender and sexual diversity using a critical approach for educational materials design. Furthermore, I explore how students' designs reflect their varying responses toward critical literacy as well as issues related to sex, gender and sexual diversity.

It therefore becomes important to understand what a critical approach means. Kumashiro (2002) explains that "critical pedagogy," which includes critical literacy but also expands over all learning areas, includes four main approaches (pp. 40-54). The first approach, "Education for the Other," identifies 'different' or marginalised identities and creates spaces for them within the school and curriculum (Kumashiro, 2002, pp.32-39). By differentiating between 'normal' and those in need of support because of difference, there is the risk of constructing marginalised students as lacking. This is not to say that support systems are not useful, but does require caution in how these support systems are constructed. The second critical approach, "Education about the Other," requires teaching about 
marginalised or oppressed groups (Kumashiro, 2002, pp. 39-44). This, however, could develop anthropological distance between the classroom and the group(s) under study. Again, while it is important to have information about marginalised and oppressed groups, it is how we use it to construct these groups that require care. Thirdly, "Education that is critical of privileging and Othering" is another approach to critical teaching and learning discussed by Kumashiro (2002, pp. 44-50). It is this third perspective that I draw on most in my present study. This perspective includes "a critical awareness of oppressive structures and ideologies, and strategies to change them" (Kumashiro, 2002, p. 45). Teaching and learning here requires that learners identify their normative socio-cultural constructions and then deconstruct them to determine how power works in their contexts. It is "unlearning or critiquing what was previously learned to be 'normal' and normative (Britzman, 1998)," (Kumashiro, 2002, p. 46). The shortfall of this approach lies in its focus on representation and the assumption that discursive deconstruction necessitates social action. Lastly, the fourth of Kumashiro's perspectives, "Education that changes students and society" (2002, pp. 50-54), works to answer the problem of social action. It understands that "oppression is produced by discourse, and in particular, is produced when certain discourses (especially ways of thinking that privilege certain identities and marginalize others) are cited over and over" (2002, p. 50).

Dealing with representation is about 'un-closeting' gendered and sexual identities in the classroom - including homosexual, bisexual, transgender intersexed and even the diversity in heterosexuality. By deconstructing heteropatriarchal order, and then exploring the non-hegemonic identities that traditionally exist outside of these confines, it might be possible to make topics related to sexual diversity salient and approachable to a diverse audience, including pre-service English teachers. By bringing gender and sexual hegemonies to the forefront in English language classrooms, teachers could develop critical practices in their learners. That is, learners should be taught how to question the discourses they speak 
and how those discourses influence their ways of seeing, thinking, doing and believing, especially as manifest in their use of the English language.

In this chapter, I therefore provide a brief overview of what it means to do critical literacy and how it was used in an English course I designed for Bachelor of Education (B.Ed.) students, at the Wits School of Education (WSoE) of the University of Witwatersrand in Johannesburg, South Africa. The B.Ed. student-teachers who attend my critical literacy course either major or sub-major in English language teaching and often go into public or private schools across Gauteng province or other parts of the country to teach English as a first or additional language. Furthermore, the student body comprises of those specialising in young children's education, primary or secondary education. And, given South Africa's history of apartheid, post-apartheid transition into democracy and current calls for decolonized institutions and practices, the English language teaching courses in the WSoE B.Ed. degree seek to engage student-teachers with critical literacies and pedagogies that confront controversies such as race, gender, or class.

Therefore, the purpose of the critical literacy course was to confront issues related to gender and sexual diversity, as one example of hegemonic order in South Africa and globally. More specifically, the pre-service English language teachers were required to produce their own materials for engaging with gender and sexual diversity in the English classroom. I discuss the kinds of risks that students were prepared to take, or not, while the materials they produced reveal the slippery landscapes that come with confronting real and uncomfortable issues, identities and ideologies.

\section{Critical Literacy, The Politics of Representation, and the Critical-Minded English}

\section{Language Teacher}

Representation is in part a concern with the question 'Who is the Other?', and 'What do they look like?' It is a political concern for how society constructs 'normal' and its binary Other, 
and how this plays out in language use: from literature to filmic media, in overtly political spaces to the profoundly ordinary texts of our everyday lives. This happens in different ways: as either defining how the Other can be normal (what and how we should be) or as constructing the normal as not the Other (what and how we should not be) (Kumashiro, 2002). It is, then, through repetitive representation, in text formation and of the body, which helps to establish hegemonic socio-cultural norms for performing sex, gender and sexuality (Butler, 1993). Adding a critical literacy approach to English language teaching and learning means thinking about power: who is included and who is excluded? Who gets a chance to speak and who speaks for whom? What representations are dominant and why (Janks, 1993 and 2010a)? This socio-cultural approach involves placing language education into context. Doing this permits both teachers and learners to tease out the power relations at play in their lives.

An example is a series of short adverts aired by the Kia motor company in 2013. The adverts use animated stickers on the back windscreen of various Kia cars on the market. These stickers were stick-figure drawings of people (male and female adults and children) and common pets surfing, reading, or just posing. On the road, people buy these stickers to represent their own families. The television adverts use the slogan "no matter how your family starts, make sure they end up in a Kia", thus showing the different ways that people could meet and fall in love - to eventually establish a family unit. In one advert, a man playing golf strikes the golf ball and hits another male golfer on the windscreen. He yells, "Sorry!" as the other man turns around. When they face each other two hearts appear above their heads to signify their attraction. The utter surprise of seeing this on television, especially in such a normative and understated way, caused me and my partner to rewind and re-watch the advert three times. We were in a state of disbelief that same-sex attraction could be represented without stigma, stereotype or hyperbole. 
As suggested by the Kia advert, the role of representation is to reify the changing values of a society. Under hegemony, those values must be accepted by both the subaltern and the hegemonic in order to reproduce and maintain power relations; meaning that representations are always positioned. And, in order to reach equitable representation, especially of previously marginalised groups, we must ask critical questions (Janks, 2010a; McLaren, 1995).

The critical in critical questioning is that which addresses how power relations are established through language and representation. That is, how does text work to position us? Some groups are represented whilst others are marginalised, misrepresented or completely silenced (Connell, 1995). This entails considering literacy as a socio-cultural process for meaning-making where literacy is the ability to read the word and the world (Freire and Macedo, 1987), and therefore to 'write' the word and world into being as well. Our methods for constructing and interpreting the places in which we live are contextually bound in time and space. Our languages, cultures and social values all contribute to the possibilities of representation.

However, this also implies that the 'world' is relative. From the everyday experiences of home, work and social life to the issues of larger political and economic power, 'world' pertains to the environments that constitute personal lives. For many, this is only as large as local communities while for others it may encompass global issues of governance. This can be distinguished as "Politics with a big $P$ and $p$ olitics with a small $p$ " (Janks, 2010a, p. 186). In a hyper-mediated world, global big-P politics do enter the personal lives of individuals, but lives are dominated by the little-p politics of normativity: the everyday texts that normalise and naturalise hegemonic order. The $2013 \mathrm{Kia}$ advert is an everyday text that subverts conventional notions of 'falling in love' in the households of South African people - albeit 
only those with satellite broadcasting. It is understated and subversive magic that works to normalise same-sex, albeit only gay male, attraction.

Ironically, how everyday texts could work to normalise the identities and representations of marginalised and silenced groups is also how current hegemonic texts work to set up inequitable power relations. Through repetition, 'nature' is constructed. The task, then, is to deconstruct normativity in ways that reveal its constructedness (Butler, 1993 and 2006; Janks, 2010b). Fairclough's (1989) model for 'critical discourse analysis' becomes a useful framework for understanding how texts work in sociocultural contexts to establish and maintain relations of power.

Fairclough's (1989) model shows three boxes, each placed inside the other like babushka dolls. The inner most box is labelled description, the middle box interpretation and the outermost box explanation (Fairclough, 1989). Description involves the reader "engag[ing] with the physical text and its use of language. It allows him/her to consider the role of particular linguistic devices, their interactions, as well as their contribution to the whole meaning of the text" (Govender, 2011, p. 62). The reader must be able to access meanings in the text, while the text designer needs to consider where and to whom the text will be accessible.

Under interpretation, the text undergoes processes of production and reception (Fairclough, 1989; Janks, 2005a). Here, the text is constructed following a number of choices: Who is the intended audience? What linguistic devices can be used to address this audience? Who is included and excluded, and how are they represented? The answers to these questions, whether determined consciously or not, emerge from hegemonic traditions for constructing texts and representing people or institutions. Similarly, the reader, in their own socio-cultural context, reads the text under their own set of hegemonies. If the two contexts, of designer and reader, are aligned the reader will be an ideal reader and accept the 
text easily. However, if the two contexts and their values are misaligned, the reader might ask critical questions, easily, in order to resist the positioning power of the text. Meaning-making potential, then, is realised in relation to people, context and time.

This leads to Fairclough's (1989) outermost box, explanation, which considers the allowances of our contexts: what is imaginable under the hegemonies at work? What is allowed to be said, and how? In what ways would it be possible to resist the text, and are there consequences? Hegemonic order enables (self)regulation, which enables the (re)production of normative texts. It is in this 'box' that we can consider how power works with(in) the text and the people who interact with texts, as well as what in our history, politics, economics, religions and cultures help us to regulate and police ourselves.

Through the latter two 'boxes', teachers could intervene to consider what other, nonhegemonic possibilities exist - especially when texts can be prescribed by schools and governments. It is within these spaces that our students and learners can explore different perspectives, ways to read, options for designing texts as well as explore the possibilities for re-imagining texts in more equitable forms.

However, what can be considered a 'text' is more than just printed words. While traditional texts still play a pertinent role in literacy practices inside and outside of the classroom other communicative modes have rapidly become more accessible and useable in everyday and formal educational settings. From multimedia texts in digital spaces to printed visuals in the media, our understanding of what makes a text has expanded into a theory of multimodality (Kress \& Van Leeuwen, 2001).

A critical approach to teaching and learning requires, then, an understanding of how to teach the multiple skills for making meaning from various modes. That is, to move from literacy to literacies (Ferreira, 2009) and, furthermore, to develop an understanding of how different modes influence each other's meanings (Unsworth \& Cléirigh, 2009). In pluralising 
literacy, we need to understand that reading as a process for making meaning happens not only in formal settings for learners. Rather, it is something that happens all the time: we read billboards, election posters, newspapers, road signs and cereal boxes. We read newspapers, listen to the radio, feel brail on elevator buttons, taste cultural occasions and smell socioeconomic circumstances. It is, then, part of the role of the teacher to bring these texts into the classroom and help learners to understand their positioning power (Ferreira, 2009). Critical literacy, or critical multiliteracies, should then push learners into considering power, and how a variety of modes enable texts to serve different interests. And, under hegemonic order, it is the value system of the subaltern that needs to be addressed in order to transform hegemony itself. Classrooms, including those dedicated to English language learning, can become creative spaces for social transformation, awareness and justice.

In order for English language teaching to become critical, the pedagogies of critical literacy (Janks, 2010), critical antioppressive pedagogy (Kumashiro, 2002) and the practices of critical discourse analysis (such as Fairclough, 1989) need to be adopted by both teacher and learner. This follows the understanding that

There is growing recognition that when a language learner reads or writes a text, both the comprehension and construction of the text is mediated by the learner's investment in the activity and the learner's sociocultural identity (Norton, 2008, p. 1815).

Therefore, both teacher and learner must invest in the negotiation of identity, context, language use and convention, and the relationships of power across these categories. Critical literacy enables "[calling] languages into being” (Makoni \& Pennycook, 2005, p. 143) so that it may be unmade and remade in more socially just ways: from identifying and deconstructing texts and discourses, to imagining more socially just futures, to using language to (re)construct identities, societies and social participation. But, this does not just happen: initial 
teacher education for English language teachers must engage with and prepare pre-service teachers of English in ways to confront controversy through critical literacy practice as well.

\section{Social Context}

South Africa's history of racial apartheid informs the current racial, religious and linguistic fragmentation that still persists. If we reread South African history, however, it becomes evident that gender and sexuality were also concerns for the apartheid government. For instance, the kinds of sex that people were permitted to engage in became legislated (Gevisser \& Cameron, 1994), while Retief (1994) shows how publishing restrictions affected how we saw, and still see, nonheterosexual identities. This resulted from censoring publications and mass media as "attempts to ensure that homosexuality is kept out of the sight and mind of the general public" (Retief, 1994, p. 104) and to hence place nonconforming gender performance and relationships outside the hegemonic order resulting in homophobic social responses (McCarl Nielson, Walden \& Kunkel, 2000; Nkoli, 1994; Gevisser \& Cameron, 1994; Luyt, 2012; Cameron, 2006; Thurlow, 2001; Reddy, 2009, 2012; Mkhize, Bennett, Reddy \& Moletsane, 2010; Msibi, 2012a, 2012b).

The persistence of homophobic responses to 'gender violations' in order to regulate and maintain traditional ideas of sex, gender and sexuality (McCarl Nielson, Walden \& Kunkel, 2000) becomes an issue in education, whereby learners are socialised to engage in particular cultural gender roles, determined by their sex. And, this is not an isolated concern: from Luyt's (2012) study of the construction and maintenance of dominant ways of performing masculinity in South Africa through talk, and similarly, Cameron's (2006) revealing analysis of heterosexual college men's talk to affirm their own sense of masculinity through the Othering of men identified as gay and the evaluation of women's breasts; to Thurlow's (2001, p. 25) qualitative account of "homophobic pejoratives [and] verbal abuse" in a United Kingdom high school. The ways in which genders and sexualities, and their 
'violations' (McCarl Nielson, Walden \& Kunkel, 2000) elicit patterned responses of homophobia or heterosexualisation reflects the ongoing and tireless work of hegemonic ideologies. Critical literacy thus becomes an important tool for making the social effects of representation visible by developing an awareness of how texts work in society to (re)produce problematic power relationships.

How, then, can we envision English language education? While critical literacy has a long history in South Africa - from People's Education to the inclusion of critical language awareness assessment standards in South Africa's National Curriculum Statement (DoBE, 2003; in Govender, 2011). Recently, the Curriculum and Assessment Policy Statement (DoBE, 2011) backgrounds critical literacy in South Africa. This is troublesome considering the consistent reports on homophobia, 'corrective rape' of predominantly Black lesbian women, and bullying in schools that serves to regulate hegemonic masculinities. Education needs to take up its social justice agenda again.

Furthermore, higher education, especially initial teacher education, has not always dared to engage students with theories of gender and sexual diversity in critical ways. From Bennett and Reddy's (2009) study, it was found that while a number of faculties and departments across a range of universities in South Africa did, in some way or other, address issues of sex, gender or sexuality, the conditions for teaching and learning as well as the complexities associated with the theories were a major hindrance. That is: it seems that only those "taking the politics of gender seriously in the construction of sexualities [...] were selfidentified as feminists or explained that they were 'interested' in feminism” (Bennett \& Reddy, 2009, p. 250). This tendency became apparent across the board in South African universities, including their English language classes.

Similarly, Francis and Msibi's (2011) work with student teachers shows the possibilities for an education that pushes students to confront gender and sexuality in South 
Africa. In their study, postgraduate students could choose an elective when registered for a course entitled Social Justice Education. One elective module dealt with heterosexism and homophobia. These students dealt with issues related to languages and gender, religion and heterosexism, racism, and teachers' fear to confront sensitive topics. However, it was also attended by only those students who were already invested in the topic.

What is needed now is a teacher-education course that is located within a more mainstream curriculum, such as English language teaching and scholarship, so that it engages with students across a variety of positions, investments and interests whilst still using critical pedagogies bent on social justice. The critical literacy course in this study does this. It is a compulsory course for English (sub-)majors that uses critical literacy to engage with pertinent, controversial topics. The Wits School of Education (University of the Witwatersrand) comes from a history of resistance to problematic norms and legislation: from antiapartheid movements, feminist and queer scholarship, to the current state of political transition. The critical literacy course draws on this history and institutional position, while still being critical of it, to engage a diverse student body with the capacity to teach and learn English in critical and socially transformative ways.

\section{Methodological approach: The Task}

In the final leg of the course, the pre-service English teachers were required to use a critical literacy approach to design their own materials for teaching an aspect of sex, gender and sexuality, as well as the conflations between any two of these concepts. Topics could include everything from family structures or relationships to any one of the identities in the LGBTI+ acronym or heterosexuality. In this way, I hoped that these students would not only engage with issues of gender and sexual diversity, but also explore the possibilities and affordances that come with adopting a critical literacy approach. This includes a range of practices: from locating effective texts and relevant information, to deconstructing texts or social systems and 
envisioning ways to engage learners in socially transformative work (Janks, 2014).

Furthermore, students' materials constitute the discursive manifestations of their own transforming understandings.

Such a task would have to incorporate not only what critical literacy means and entails, but also how gender and sexual diversity is evident in everyday representations. I have thus phrased the assessment task as follows (Figure 7.1):

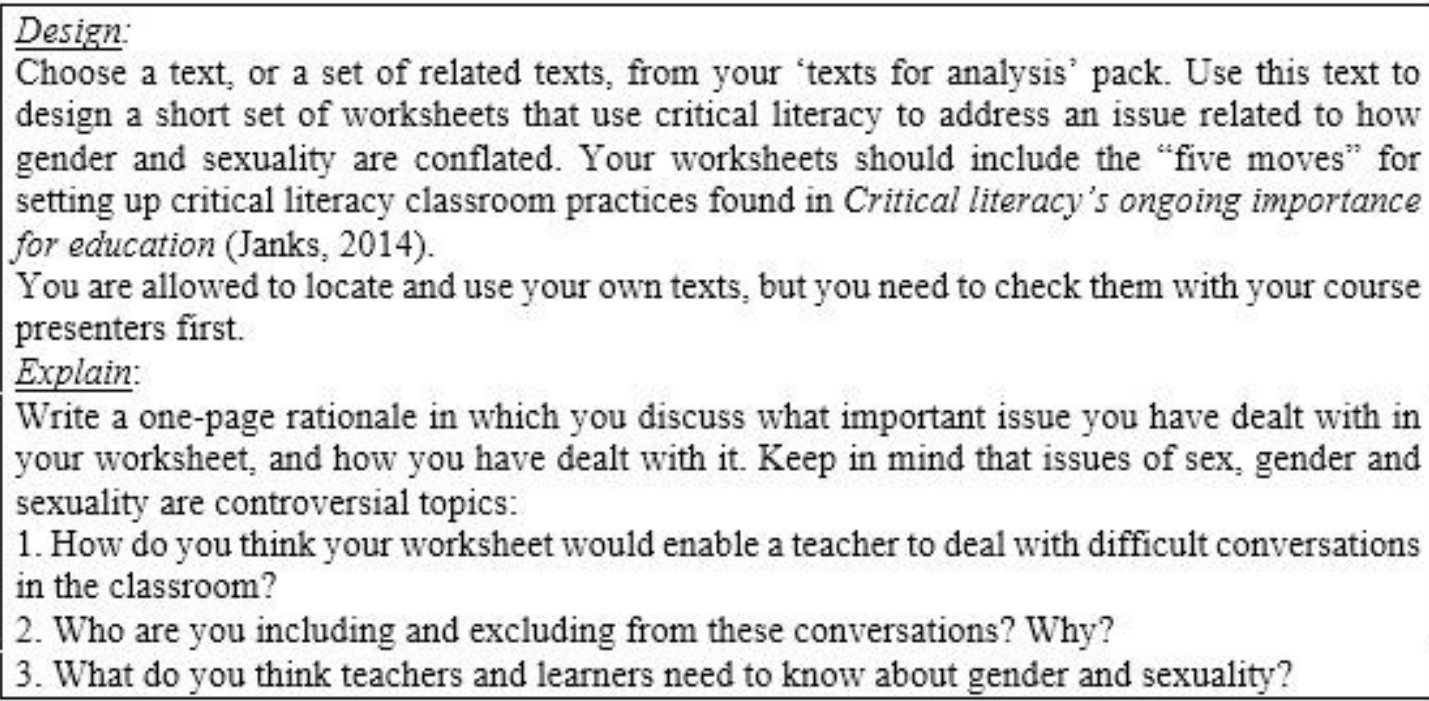

Write a one-page rationale in which you discuss what important issue you have dealt with in your worksheet, and how you have dealt with it. Keep in mind that issues of sex, gender and sexuality are controversial topics:

1. How do you think your worksheet would enable a teacher to deal with difficult conversations in the classroom?

2. Who are you including and excluding from these conversations? Why?

3. What do you think teachers and learners need to know about gender and sexuality?

\section{Figure 7.1 Course Assignment}

There are two parts: the first deals with the practical use of critical literacy in designing a set of materials for teaching gender and sexual diversity in the English classroom, using a range of texts and activities. In some ways, these materials may come to represent students' own designs and positions

The second part of the assessment involves students critically reflecting on their designs: from decisions about what identities to include and exclude, to the knowledge and subjective truths made accessible to learners. The students are not only required to show their understanding and use critical literacy, but also the ability to critique their own designs. Above all other principles, taking on a critical position means recognising that we, even as teachers, are available for critique and that our own pedagogies have a real social impact. 
It therefore became an imperative to use Biggs' (1996) constructive alignment which fundamentally involves making inextricable links between pedagogy, content knowledge or skills, and assessment. Each of these facets of the classroom needs to be informed by the other to ensure that what is being taught and how matches with assessment criteria: To do this:

(1) The criteria for assessment must be "authentic" to the discipline.

(2) To really understand the content, means changing the way one behaves in the topic area.

(3) Teachers need to specify such "performances of understanding" for the material they are teaching (adapted from Biggs, 2003; including direct quote from Gardner, 1993).

Assessing the students' understanding of critical literacy, then, is only possible by measuring their 'behaviour' (Biggs, 2003) in the field. With an effective use of critical literacy practices, techniques and tools, the students would be displaying their "performances of understanding" (Biggs, 2003, p. 3) of the approach. In order to perform the role of critical literacy material designer effectively, students would have to implicitly draw on their understanding of critical literacy.

Also, the assignment asks students to use Janks' (2014, p. 2) “five moves” of critical literacy to think about and structure their materials. This is based on the understanding that any critical literacy project is comprised of five steps: Firstly, teachers and/or learners need to identify an issue in their lives. This could range from little-p (Janks, 2010a) concerns like excluding kindergarten students from a school event (Vasquez, 2001, 2008) to more global concerns about the marginalisation of minority groups or the misuse of the environment's resources. 
Secondly, teachers and learners will need reliable information (Janks, 2014) from a variety of sources: However, what information is available? Where is this information found? Who produced it and who controls it? Whose interests does this information serve? In locating information, it is still vital that teachers and learners ask of their sources the critical questions that will help them to understand why the issue they have identified exists in the first place.

In moves three and four, teachers need to help learners understand how the issue becomes manifested through texts and how these texts function in various socio-cultural context s (Janks, 2014). That is, learners need to begin identifying texts such as articles, advertisements, policy documents and so on that represent the issue in a variety of contexts, followed by deconstructing these texts in order to explore how they function within those contexts. Furthermore, Janks (2014) identifies that (re)design (New London Group, 2000), or reconstruction (Janks, 2005b, 2010a, 2010b), forms an integral move for creating a critical literacy project. It is in this final move that teachers and learners can use their understanding of the social impact of texts, language and representation to engage in socially transformative work.

As a whole, Janks' (2014) fives moves provide a practical framework for the students in the critical literacy course. It allows for the production of materials that entice critical engagement with a particular social issue: from identification, to analysis, to (re)design. By constructively aligning the course content and pedagogical approaches with the assessment, and scaffolding the task by using Janks' (2014) five moves, the critical literacy course culminates into an expression of the potentials for critical literacy itself. How comfortable are student teachers of English language with addressing certain sensitive topics in the classroom? How well do students engage with the content on sex, gender and sexuality? 


\section{An Analysis of the Usefulness of Gender}

From the 31 assignments that include gender as a topic or as part of an activity, four main uses of gender can be identified: (1) to introduce a discussion or activity; (2) using gender to deconstruct normativity; (3) to avoid queer discourses; (4) to engage with 'subversive' gender identities.

I now provide one example of a designed course material related to each of the above four uses of gender, as emergent from the study. The course material related to (1) is labelled Figure 7.1 (below); the material related to (2), as Figure 7.2 (below); the material related to (3), as Figure 7.3 (below); and the material related to (4), as Figure 7.4 (below).

To begin, Figure 7.2, one of the English course material designed by the students, shows how some students use issues of gender, gender roles, biological sex and the conflations between these to introduce their materials and instigate discussion. 
Activity1. Write the meaning of the words in the shapes
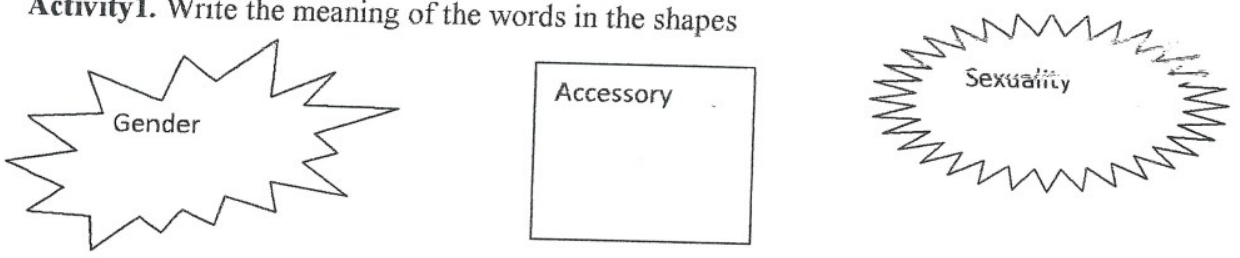

The usage of accessories (gender and sexuality)

Society seems to be concerned about the use of accessories. These (accessories) range from shoes, jewellery, bags, make-up, tattoos to hair styles and they enhance the beauty of people but they are non-essential (see Appendix)

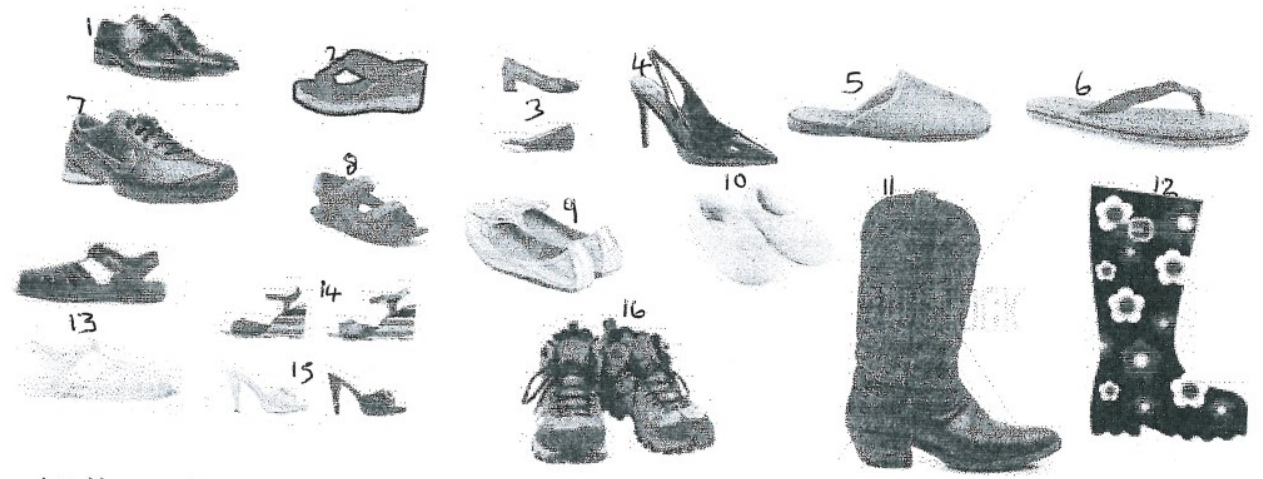

htt://www.shutterstock.com/pictures: http://www.bigstockphoto.com/search/cowboyboots/http://www. claks.co, uk

Activity 2: a) Name the type of shoe and place it on the appropriate section on the table.

\begin{tabular}{|l|l|l|l|}
\hline Female & Male & Unisex & Other (state) \\
\hline & & & \\
& & & \\
& & & \\
\hline
\end{tabular}

Activity 3: What was your criterion for placing the shoes and other accessories? Gender or sexuality? Give reason.

$$
\text { (Appendix) A Why? }
$$

N/B Write the meanings of the following words, Straight, bisexual, gay, lesbian, androgynous, asexual and any other type of sexuality not mentioned.

\section{Figure 7.2 Using Gender as an Introduction to Learning}


However, not all introductory activities take a critical turn, as is shown in Figure 7.2 above. For instance, in this activity, the English language student would be limited to the identification of biological sex and/or gender markers and do not necessarily consider ways of making the constructedness of these categories more apparent. These markers that learners habitually use to construct these representations needs, then, to be followed by a critical reflection.

This reflection seems evident in the next course material, which is Figure 7.3 below. This material illustrates how questions about sex and gender can contribute toward deconstructing assumptions about what makes a family and how gender is often used to identify who plays what role in families: 


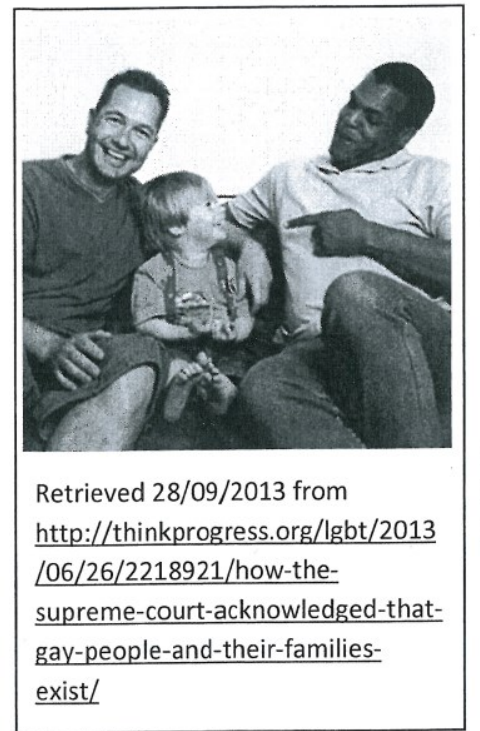

06/26/2218921/how-the-

gav-people-and-their-families-

\section{What makes a family?}

1. Individual activity

Write a paragraph describing what you see in this picture. Who do you think each person could be in this picture?

\section{Group activity}

Get into groups of five and read your paragraph to the group. Share what you thought of the picture. Did the other people in your group have paragraphs that said the same thing you did?

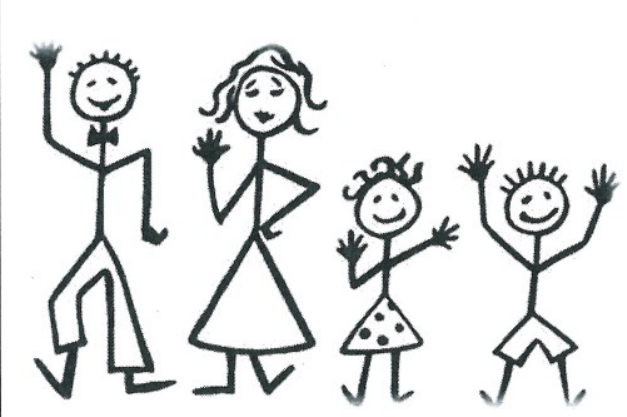

Retrieved 28/09/2013 from

http://www.cairns.com.au/article/2013/01/19/2 38544 local-news.html

4. Individual activity

\section{Group activity}

3.1 What is this picture of?

3.2 How do you know? Describe what you see.

3.3 What is 'gender' and 'sex'? (Use dictionary to help you)

3.4 Who says that this how moms, dads, boys and girls should dress?

3.5 Do the clothes drawn in this picture show us ande gender, sex or both? Explain. How ARE CRRESTE

3.6 Do you agree that this is what a family should look like? Discuss.

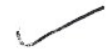

4.1 Draw a picture of your own family.

4.2 Write a paragraph describing each person in your picture and who they are in your family.

Homework activity:

Find pictures of families and family members in magazines and bring them to class with you.

Page 1 of 11

Figure 7.3 Moving into Deconstruction 
In activity three of this material, the English language learner is required to analyse a comic representation of a normative family structure: mom, dad and two kids are shown as stickfigures. All of them are happy. But, more importantly, all of them are identifiable as a result of their gender performance (Butler, 2006). The father wears a bow-tie, long trousers and has short, cropped hair; the mother dons a skirt, long hair and a hand on the hip; a young girl also wears a skirt and has visibly longer hair than her brother next to her who has short hair like the father and wears a pair of short trousers. The people here seem to represent conventional, middle-class, age-appropriate and heteronormative constructions of family. And, given their smiles and exuberant stances, they are seemingly happy to do so.

However, this pre-service English teacher has then used some simple questions in activity three to help learners notice what this text is doing (cf., questions 3.1-3.6 in Figure 7.3 above). Questions 3.1 and 3.2 seem to function within Fairclough's (1989) inner-most box of his model for critical discourse analysis. That is, they require learners to describe the text and to become aware of its construction. Thereafter, issues about gender performance are introduced (cf., question 3.3). On its own this question is not necessarily critical, but it does provide space for learners to engage with the conceptual underpinnings of gender itself. That is, once they identify who is in the picture and what their own criteria was for deducing this, learners then have the opportunity to measure their own understanding against another source of information. Furthermore, in questions 3.4, 3.5 and 3.6 (in Figure 7.3 above), the English learners might discuss where these ideas about gender and sex come from and whether or not they are legitimate by asking "Who says that this [is] how moms, dads, boys and girls should dress?" Teachers and learners might be pushed to consider whether the ways they do gender are natural, given criteria or if they are performative, constructed. Furthermore, by then applying newly learnt concepts to the evaluation of learners' own families, these materials use gender to help learners deconstruct normativity in meaningful and relevant ways. It is 
through engagement with these last few questions that teachers and learners might begin dipping into Fairclough's (1989) two outer boxes: interpretation and explanation.

Figure 7.3 uses common assumptions about gender. While issues of gender and sex are introduced from activity three, activities one and two presumably attempt to draw out learners' assumptions about what families look like. The same image of two adult males and a young child referred to in these activities is used again in the final activity. Learners move from assumption, to description and evaluation, to deconstruction and re-evaluation throughout the material. And while the questions and activities themselves contribute to the critical positions and intents of this set of materials, it is also noticeable how the sequence of activities enables learners to make critical moves in practice and understanding.

However, if the usefulness of gender is defined by its juxtaposition with textually deconstructive practices, then the following examples illustrate avoiding queer identities. The types of activities, and their sequencing, in these students' materials are restricted to identifying and then categorising normative characteristics of male and female or masculine and feminine. While this might be useful in some cases, it can also be problematic when these activities do not deal with issues of power, marginalisation, nonconformity or subversion. This seems clearly illustrated by Figure 7.4 (below). 


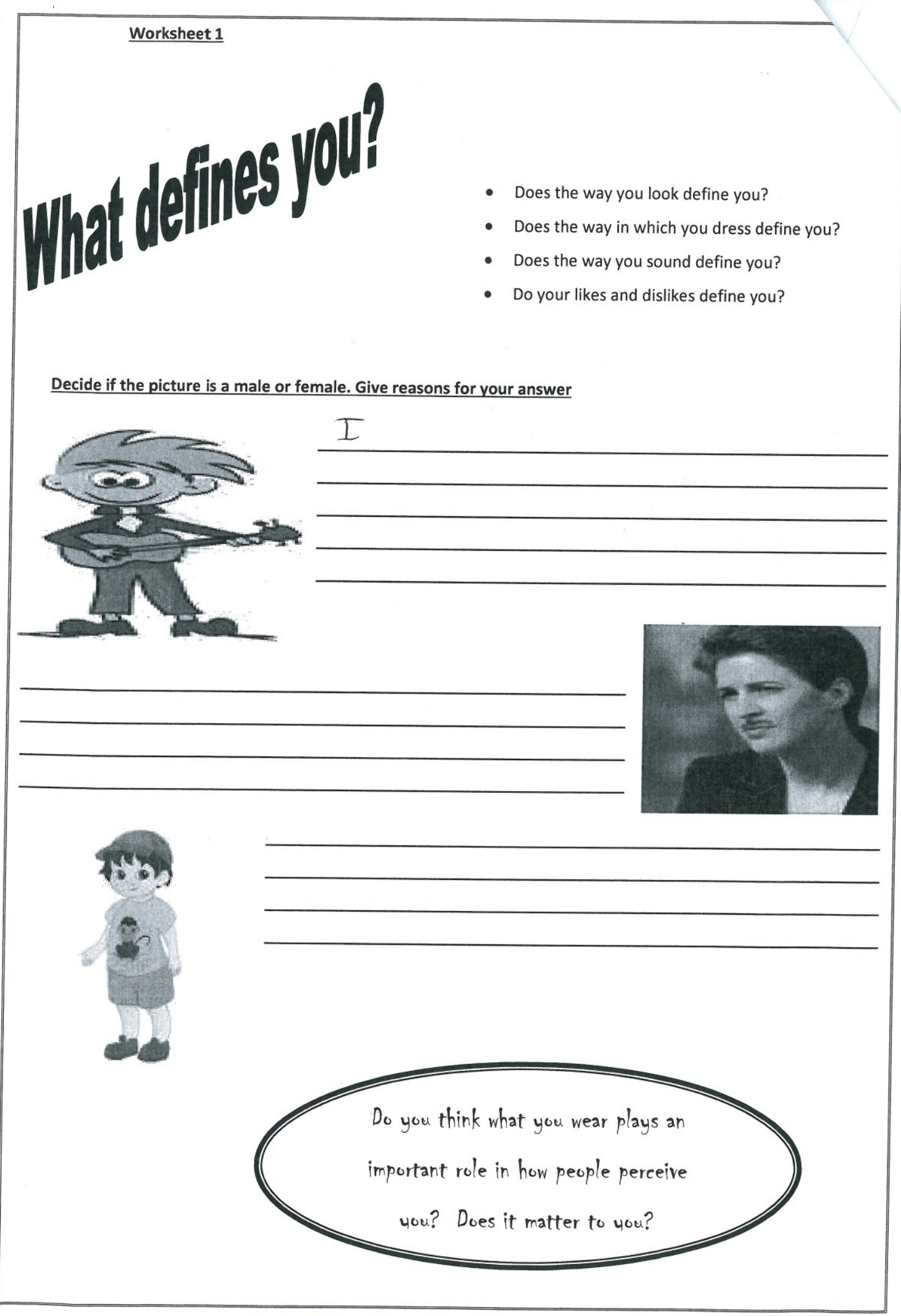


lorksheet 2

Which speech bubbles do you think were for males and which speech bubbles were used for females?

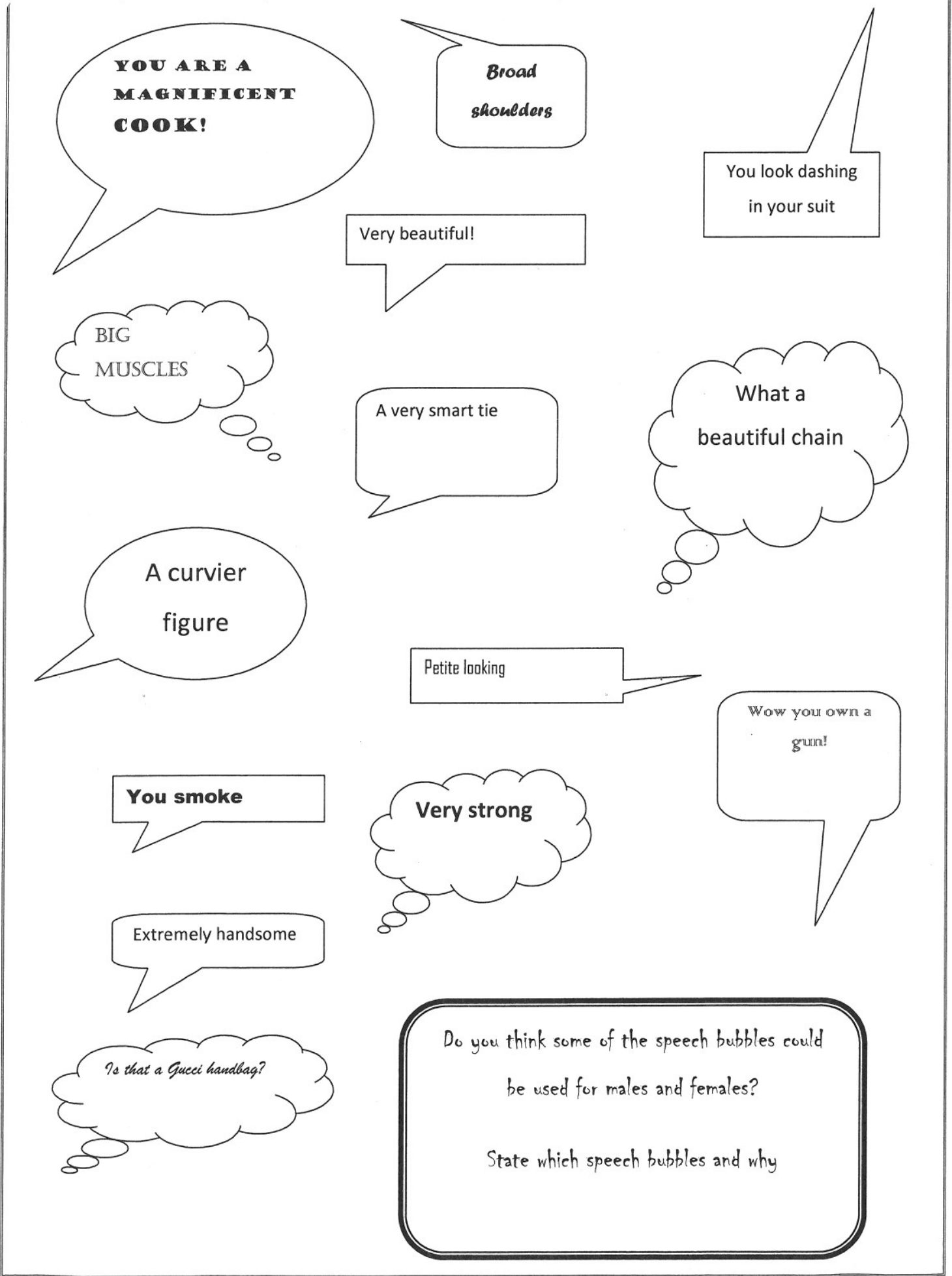

Figure 7.4 Avoiding Queer Discourses 
Here the questions of identity and subjectivity seem short-lived. Following the first instruction are a series of activities that focus on identifying whether things (images, phrases, sports, colours, and accessories) are either 'male' or 'female', 'for males' or 'for females'. Without any interrogation, this activity conflates representations of sex and gender. As shown in Figure 7.4 above, presenting activities in this way maintains normative conflations of sex and gender rather than disrupting them; and identification and categorisation according to a conventional male-female binary is repeated in various forms:

- Look at the different sport activities. Choose which sport do males play and which sport females play.

- Choose which colours are mainly used for females and which colours are mainly used for [males].

- You bought presents for your two best friends one is a boy and one is a girl. Decorate the box according to which colours your friends would like.

- Choose whether these activities are suitable for a male or a female.

Therefore, when it comes to considering how the students in the critical literacy course have engaged with gender and sexual diversity through their materials, I cannot overlook how these students have either confronted or avoided queer identities that displace commonsense in English language teaching. And while gender is useful for maintaining gender role theory (Bilodeau \& Renn, 2005), it is also useful for disrupting convention and tackling difficult conversations.

In some cases, using gender as a starting point has allowed students to locate and include texts that disrupt gendered norms. Their use of subversive texts was either sourced from the critical literacy course pack or other media. Figure 7.5 (below) indicates how texts from the course pack were used: 
Worksheet 3

\section{South Africa's First Traditional Zulu Gay Wedding}

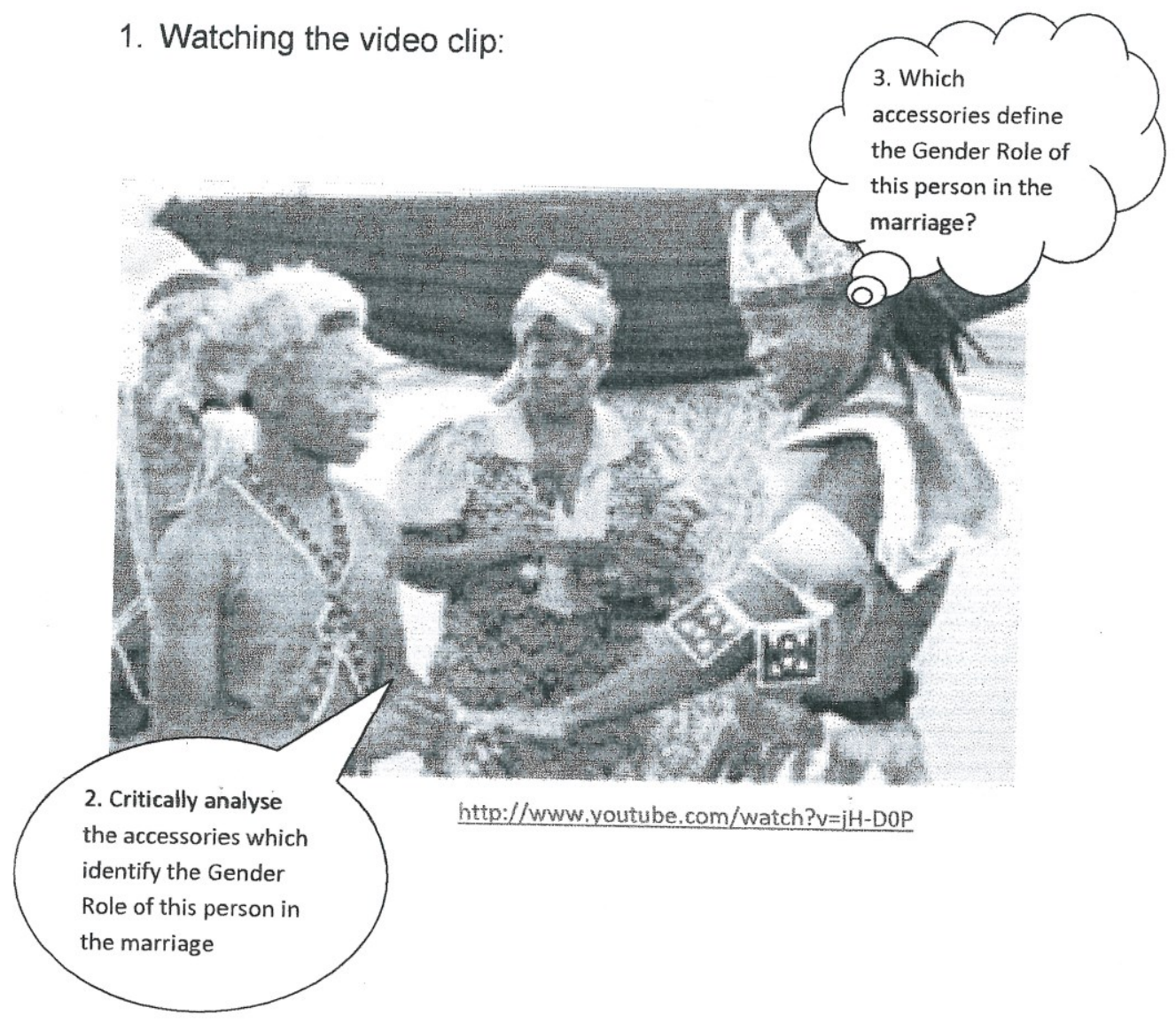

South Africa has legalised the marriages of the LBGT community since 2006. This wedding was legal and accepted by law. The couple's wedding was carried out in the Zulu traditional way of wedding.

Activity 7) Answer the questions in the bubbles.

Activity 8) Learners will debate with the aid of the video they watched: The accessories you wear identify your gender and sexuality.

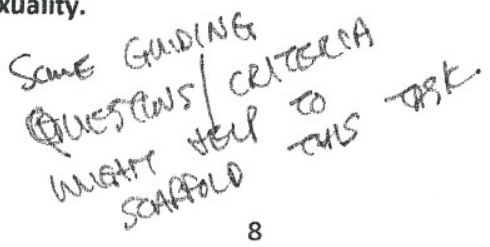

Figure 7.5 Using Subversive Texts 
This English course material, as designed by one of the pre-service teachers, incorporates images from an article by Lenox Magee (2013), South Africa's First Traditional Zulu Gay Wedding. Firstly, using an introductory activity in this set of materials that focuses on how accessories are used to express gender identity, the material would then lead the learners to the article by Magee (2013). Using what they have identified and then disrupted about gender performance, learners now analyse the more subversive text of an African gay wedding in relation to gender performance through the use of accessories.

\section{Hyperinclusivity: Negotiating the Discourses of Sameness and Difference}

In this section, based on the above analysis of the four English course materials designed by the pre-service teachers in my class, I discuss how the words and expressions that come from discourses of social justice and transformation have been used to construct representations of sameness. Throughout so many materials, discourses of sameness have emerged again and again: From issuing and reiterating critical literacy’s human rights agenda, to making reference to South Africa's constitution which states the protection of all against discrimination based on gender and sexual orientation, to coming to terms with the discourses of sameness and difference that emerge during conversations about diversity. However, it is the particular ways in which these students use human rights discourses that an almost new discourse emerges.

This is the discourse of hyperinclusivity: an exaggerated and repetitive use of human rights and socially transformative discourses in order to create a representation of sameness that is almost utopian (Figure 7.6). This is done with particular use of the language of human rights, equality, equity and social justice. However, the use of this kind of language, as desirable as it sounds, appears superfluous: 


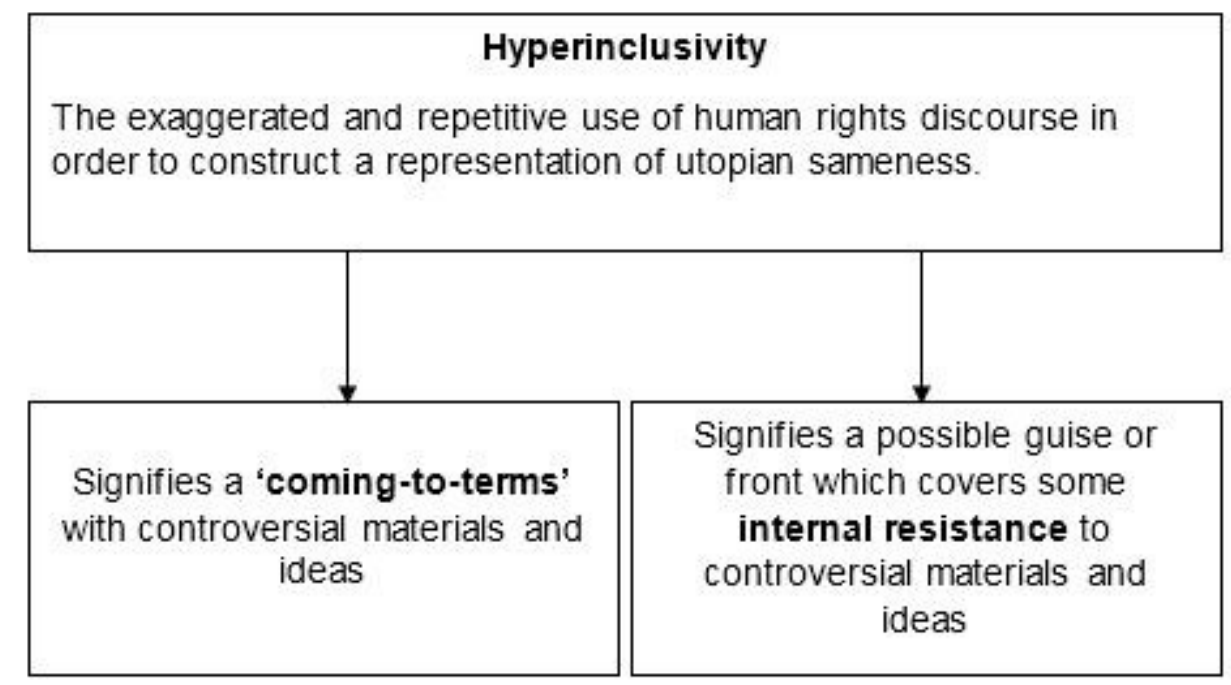

\section{Figure 7.6 Model for Discourses of Hyperinclusivity}

Throughout the conversations about diversity that took place during class and in materials design, with a particular focus on the above four materials, the negotiation of the discourses of sameness and difference emerged. It would seem, however, that this type of negotiation was also related to how the pre-service teachers engaged with the kinds of diversity often considered sensitive, controversial or condemned. Gender and sexual diversity fits this description throughout the materials designed by students; and there are traces of their own negotiations, their own 'coming to terms with', a queer perspective in English language teaching. However, it is this issue of acceptance that 'comes too easily' that I am sceptical about.

What is interesting to note is the common juxtaposition of hyperinclusive language use with the language of masked resistance. The reasons for this 'resistance', however, is not always clear but could emerge from either disagreement with some positions or an illustration of adjusting schemata as English education students come to terms with how to confront gender and sexual diversity.

In some students' work, hyperinclusivity also became evident in the (re)design activities: 
- Create a sexual orientation awareness day and design a t-shirt that is not biased or does not discriminate against anyone.

- Take any of the advertisements above and redesign it so that nobody is excluded or loses out or is hidden.

- Create or find two new adverts that cater for all types of families be it a two mom family or a two dad family or even a single parent family etc.

- Now redesign this text in such a way that it accommodates all people according to gender, sex, race and culture.

While the attempt that these activities make to be inclusive is notable, it also negates a critical understanding that all text is positioned and positioning (Janks, 2010a). Because of this, it becomes impossible to design anything that is 'not biased' or that 'accommodates all people'. This creates a paradox between what students might envision critical literacy to be and what one is actually able to represent when decisions about identity, inclusion/exclusion, visibility/silence, power and social context have to be made. As such, the (re)design activities that are seen above seem to display how critical literacy's human rights agenda and advocacy for socially transformative work can be over-simplified.

In such activities, there exists the risk of essentialising diversity by unifying all differences and representing only sameness. And, while sameness might seem to make all things equal, it also silences the very differences that make humanity. A focus on sameness without difference might maintain the hegemonic status of some and the marginalised positions of others because the value of difference itself is ignored (Janks, 2005b and 2010a), leaving the question of whose understanding of sameness gets to be represented?

The sameness that is often stated and restated in students' materials seems to also rely on the idea of being human, as shown in another (re)design activity: 
Design a billboard which can show that homosexuals are human beings and have same rights as straight people.

In this example, the homosexual-heterosexual binary has been established and weighed against each other. The dominant form, heterosexuality, naturally constitutes being human which also means having human rights. This student, then, envisions that a socially transformative design task would be to find ways to represent homosexuals as also being 'human beings'. The question this raises, however, is whether this maintains heterosexuality as the natural norm?

In this instance, discourses of hyperinclusivity have possibly been used to mask some form of internal resistance that the student might be. Hyperinclusive language might be used to compensate for any resistances that the student may actually be feeling. It is the attempt to present one's self as inclusive by emphasising ideas of sameness, despite one's personal feelings that these identities are unacceptable or condemned.

When I consider the conceptualisation of hyperinclusivity, I am reminded of the scene of Gevisser (2014) sitting in a church service in Alexandra, Johannesburg where he takes note of the choir singing before an audience:

I did a double-take when I realised that one of the more ardent participants in this ritual was transgendered, a biological man dressed almost identically to her companion in township streetwear: tight jeans, strappy sandals, frilly tops, hoops in the ears. What differentiated her was a big wig, a little too much make-up, and oversized sunglasses that were not entirely necessary indoors. But I noticed that despite the occasional titter, the others in the hall seemed entirely unfazed by her presence: I seemed to be the only one looking at her (pp. 324-325). 
Gevisser's work with queer identities in South Africa makes him more aware of issues relating to human rights and queer subjectivity. However, at what point does it become hyper-vigilance? Considering my own position, it is because of my concern with (mis)representations of LGBTI+ people that I might be hyper-vigilant myself. To what extent, then, is my understanding of hyperinclusivity fair? Does what I consider hyperinclusive discourse actually resemble authentic attempts made by students to grapple with controversial diversities? Like Gevisser (2014), to what extent am I the only one staring at something 'misrepresented' that might actually be acceptable, functional and productive in its context?

For these students who will become English language teachers, hyper-vigilance of the multiple meaning potentials that can be embedded in English language constructions (such as speech and text) is necessary. It is in their developing capacity to see the relationships between English language use, social context, identity and power that may enable them to confront, engage and transform problematic status quos. However, from this chapter, it is easy to see that such transformation, especially of one's own position and understanding, takes time. But with time, perhaps the negotiations of hyperinclusive discourses and avoidance could become negotiations of diversity, subversion and agency.

\section{Conclusion}

The tenacity of gender and sexual hegemonies emerge throughout many of the English language course materials that have been submitted to this project, by way of my students (pre-service English language educators) from the critical literacy course I designed and carried out at the Wits School of Education of the University of Witwatersrand in Johannesburg, South Africa. In small ways - through sequencing of questions and activities, through the types of texts used - many of the materials that students from the critical literacy course produced maintain a heteronormative front. However, it might be harsh to label these 
assignments as being unsatisfactory or problematic given the short time frame of the course. Instead, these materials reveal how students use critical literacy practices to develop their understandings of gender and sexuality diversity and come to terms with new ways of thinking about these sensitivities.

In English language teaching, taking both a critical and critically self-reflective stance might enable teachers and learners to constantly participate in cyclical evaluations of how language can be used to engage with or disengage from sensitive social issues. Furthermore, it might enable the capacity to question the fundamental ways in which meaning can constructed through language in transformative ways rather than superficially hyperinclusive ways. The potential of critical literacy and strategies for materials design in ITE for English language teaching thus lies in the practices of its participants and a willingness to confront difficult conversations.

\section{Recommended Texts}

Bhana, D. (2014). Ruled by Hetero-norms? Raising some Moral Questions for Teachers in South Africa. Journal of Moral Education, 43(3), pp. 362-376.

Deconstructing and disrupting heteropatriarchal hegemonies is difficult work, but it is work that can only be done if we are able to see the norms that govern us. Bhana's work, including this article, explores the motivation and varying perspectives on gender and sexual diversity in South African classrooms - often revealing the persistence of heteropatriarchy.

Janks, H. (ed). (2013). Doing Critical Literacy: Texts and Activities for Students and Teachers. Routledge: USA.

In this book, Janks and other contributors present an activity-based resource for doing critical literacy in the English language classroom. Each chapter seeks to draw out teachers' and 
learners' capacity to engage with the relationship between English language, literacy and power in relation to a wide range of social issues and theoretical lenses.

Khayatt, D. (1999). Sex and Pedagogy: Performing Sexualities in the Classroom. GLQ: A Journal of Lesbian and Gay Studies, 5(1), pp. 107-113.

Engaging with gender and sexual diversity in the classroom often raises more questions than answers. Khayatt's work on the role of teachers' identities in sensitive classroom spaces interrogates various closet(ed) spaces and the role of coming out.

\section{Engagement Priorities}

1. What are the risks that teachers might have to take when engaging with controversial topics in the English language classroom, in different contexts?

2. To what extent does critical literacy practice fit with the educational policies and expectations of your current context? What are the ways to make that fit happen?

3. How can controversial topics be confronted in ways that are still relevant to English language teaching and learning? That is, what are the limits of language education?

4. Should both hegemonic and marginalised identities be used to develop critical pedagogies? Where is the line between critical pedagogy and activism in English language teaching?

5. If hyperinclusivity signifies a 'coming to terms' with or 'masked resistance' of new ways of seeing, doing and believing, how can teachers and learners become aware of their own hyperinclusive practices and move beyond them?

\section{REFERENCES}

Bennett, J., \& Reddy, V. (2009). Researching the pedagogies of sexualities in South African higher education. International Journal of Sexual Health, 21(4), pp. 239-252.

Bhana, D. (2012). Understanding and Addressing Homophobia in Schools: A View of Teachers. South African Journal of Education, 3, pp. 307-318. 
Biggs, J. (1996). Enhancing Teaching through Constructive Alignment. In Higher Education, 32, pp. 347-364.

Biggs, J. (1999). What the Student Does: teaching for enhanced learning. In Higher Education Research and Development, 18(1), pp. 57-75.

Biggs, J. (2003). Aligning Teaching \& Assessing to Course Objectives. In Teaching \& Learning in Higher Education: New Trends and Innovations, 13(17).

Bilodeau, B. L. \& Renn, K. A. (2005). Analysis of LGBT Identity Development Models and Implications for Practice. In New Directions for Student Services, 111, pp. 25-39.

Butler, J. (1993). Imitation \& Gender Insubordination. In H. Abelove, M. Aina Barale \& D. M. Halperin. (Eds.) The Lesbian and Gay Studies Reader. Routledge: New York and London.

Butler, J. (2006). Gender Trouble. Routledge Classics: New York.

Cameron, D. (2006). On Language and Sexual Politics. Routledge: USA \& Canada.

Connell, R. W. (1995). Masculinities. Allen \& Unwin: Australia.

Department of Basic Education. (2003). National Curriculum Statement: Grades 10-12, English Home Language. Department of Printing Works: Pretoria \& Cape Town.

Department of Basic Education. (2011). Curriculum and Assessment Policy Statement: Grades 10-12, English Home Language. Department of Printing Works: Pretoria \& Cape Town.

Epstein, D. \& Johnson, R. (1998). Schooling Sexualities. Open University Press: Buckingham and Philadelphia.

Fairclough, N. (1989). Language and Power. Longman: London.

Ferreira, A. (2009). Chapter 14: Reading Pictures. In A. Ferreira (Ed.) Teaching Language in the South African Classroom. Macmillan: Braamfontein.

Francis, D. \& Msibi, T. (2011). Teaching about Heterosexism: Challenging Homophobia in South Africa. Journal of LGBT Youth, 8(2), pp. 157-173.

Freire, P. \& Macedo, D. (1987). Literacy: Reading the Word \& the World. Bergin \& Garvey Publishers Inc.: Massachusetts.

Gevisser, M. (2014). Lost and Found in Johannesburg. Jonathan Ball Publishers: Johannesburg \& Cape Town.

Gevisser, M. \& Cameron, E. (1994). Defiant Desire. Ravan Press: Johannesburg.

Govender, N. N. (2011). Critical Literacy: Do Textbooks Practise What They Preach? In English Quarterly, 42(3-4), pp. 57-82.

Janks, H. (2014). Critical Literacy's Ongoing Importance for Education. In Journal for Adolescent \& Adult Literacies, 57(5), pp. 349-356. 
Janks, H. (2010a). Literacy and Power. Routledge: New York.

Janks, H. (2010b). Language, Power and Pedagogy. In N. Hornberger \& S. McKay (Ed.) Sociolinguistics and Language Education. Multilingual Matters: Clevedon.

Janks, H. (2005a). Language and the design of texts. In English Teaching: Practice and Critique, 4(3), pp. 97-110.

Janks, H. (2005b). Deconstruction and Reconstruction: Diversity as a productive resource. In Discourse: studies in the cultural politics of education, 26(1), pp. 31-43.

Janks, H. (Ed.) (1993). Critical Language Awareness Series. Witwatersrand University Press: Johannesburg, South Africa.

Kress, G. \& Van Leeuwen, T. (2001). Multimodal Discourse: The Modes and Media of Contemporary Communication. Arnold: London.

Kumashiro, K. (2002). Troubling Education: Queer Activism and Antioppressive Pedagogy. Routledge: New York \& London.

Luyt, R. (2012). Constructing hegemonic masculinities in South Africa: The discourse and rhetoric of heteronormativity. In Gender \& Language, 6(1), pp. 47-77.

Makon, S. \& Pennycook, A. (2005). Disinventing \& (Re)Constituting Languages. Critical Inquiry in Language Studies: An International Journal, 2(3), pp. 137-156.

Magee, L. (2013). South Africa's First Traditional Zulu Gay Wedding. Retrieved 20/05/2013 from http://www.chicagonow.com/lenox-and-the-second-city/2013/04/south-africasfirst-traditional-zulu-gay-wedding/

McCarl Nielson, J., Walden, G. \& Kunkel, C. A. (2000). Gendered Heteronormativity: Empirical Illustrations in Everyday Life. In The Sociological Quarterly, 21(2), pp. 283-296.

McLaren, P. (1995). Moral Panic, Schooling, and Gay Identity: Critical Pedagogy and the Politics of Resistance. In G. Unks. (Ed.) The Gay Teen: Educational Practice and Theory for Lesbian, Gay, and Bisexual Adolescents. Routledge: New York \& London.

Mkhize, N., Bennett, J., Reddy, V. \& Moletsane, R. (2010). The country we want to live in: Hate crimes and homophobia in the lives of black lesbian South Africans. Human Sciences Research Council: Cape Town.

Msibi, T. (2012a). 'I'm used to it now': Experiences of Homophobia among Queer Youth in South African Township Schools. Gender \& Education, 24(5), pp. 515-533.

Msibi, T. (2012b). Angeke Ngibe Isitabane: The Perceived Relationship between Dress and Sexuality among Young African Men at the University of KwaZulu-Natal. In R. Moletsane, C. Mitchell \& A. Smith (eds.) Was It Something I Wore? Dress, Identity, Materiality. Human Sciences Research Council: Cape Town.

New London Group. (2000). A Pedagogy of Multiliteracies: Designing Social Futures. In B. Cope \& M. Kalantzis (Ed.) Multiliteracies. London: Routledge. 
Nkoli, S. (1994). Wardrobes: Coming out as a Black Gay Activist in South Africa. In M. Gevisser \& E. Cameron (Ed.) Defiant Desire. Ravan Press: Johannesburg.

Norton, B. (2008). Identity, Language Learning \& Critical Pedagogies. In Encyclopaedia of Language \& Education. Springer Press: United States. pp. 1811-1823.

Paechter, C. (2006). Masculine Femininities/Feminine Masculinities: Power, Identities \& Gender. In Gender \& Education, 18(3), pp. 253-263.

Reddy, V. (2009). Perverts \& Sodomites: Homophobia as hate speech in Africa. Southern African Linguistics \& Applied Language Studies, 20(3), pp. 163-175.

Reddy, V. (2012). Homophobia, Human Rights and Gay and Lesbian Equality in Africa. Agenda: Empowering Women for Gender Equity, 16(50), pp. 83-87.

Retief, G. (1994). Keeping Sodom out of the Laager. In M. Gevisser \& E. Cameron (Ed.) Defiant Desire. Ravan Press: Johannesburg.

Thurlow, C. (2001). Naming the "outsider within": homophobic pejoratives and the verbal abuse of lesbian, gay and bisexual high-school pupils. In Journal of Adolescence, 24, pp. 25-38.

Unsworth, L. \& Cléirigh, C. (2009). Multimodality and reading: The construction of meaning through image-text interaction. In C. Jewitt (Ed.) The Routledge Handbook of Multimodal Analysis. Routledge: London \& New York.

Vasquez, V. (2001). Constructing a Critical Curriculum With Young Children. In B. Comber \& A. Simpson (Ed.) Negotiating Critical Literacies in Classrooms. Lawrence Erlbaum Associates, Publishers: Mahwah, New Jersey \& London.

Vasquez, V. (2008). Negotiating Critical Literacies with Young Children. Routledge: New York \& London. 